\title{
Shewanella corallii sp. nov., a marine bacterium isolated from a Red Sea coral
}

Correspondence

Ariel Kushmaro

arielkus@bgu.ac.il
Maya Shnit-Orland, ${ }^{1}$ Alex Sivan $^{2}$ and Ariel Kushmaro, 2,3

\author{
${ }^{1}$ Unit of Environmental Engineering, Ben-Gurion University of the Negev, PO Box 653, \\ Beer-Sheva 84105, Israel \\ ${ }^{2}$ Department of Biotechnology Engineering, Ben-Gurion University of the Negev, PO Box 653, \\ Beer-Sheva 84105, Israel \\ ${ }^{3}$ National Institute for Biotechnology, Ben-Gurion University of the Negev, PO Box 653, \\ Beer-Sheva 84105, Israel
}

\begin{abstract}
A marine bacterial strain, designated fav-2-10-0 $5^{\top}$, was isolated from the mucus layer of a coral of the genus Favia, collected from the coral reef in the Gulf of Eilat, Israel (29.51 $\left.{ }^{\circ} \mathrm{N} 34.94^{\circ} \mathrm{E}\right)$. On the basis of $16 \mathrm{~S}$ rRNA gene sequence comparisons, strain fav-2-10-05 ${ }^{\top}$ was affiliated with the family Shewanellaceae. The closest relatives of strain fav-2-10-05 ${ }^{\top}$ were Shewanella marisflavi SW-117 ${ }^{\top}$ (96.0\% 16S rRNA gene sequence similarity) and Shewanella haliotis DW-1 ${ }^{\top}$ (95.9\%). Strain fav-2-10-05 ${ }^{\top}$ was Gram-negative, rod-shaped and motile by means of a single polar flagellum and formed yellow-brownish colonies within 2 days of incubation at $26^{\circ} \mathrm{C}$. Strain fav-2-10-0 $5^{\top}$ demonstrated antibacterial activity against indicator strains and grew in the presence of $0.5-8.0 \%(\mathrm{w} / \mathrm{v}) \mathrm{NaCl}$ and at $10-37{ }^{\circ} \mathrm{C}$. The major fatty acids were $\mathrm{C}_{17: 1} \omega 8 \mathrm{c}$ $(21.6 \%)$, iso- $\mathrm{C}_{15: 0}(18.6 \%), \mathrm{C}_{15: 0}(9.1 \%)$ and iso- $\mathrm{C}_{13: 0}(8.9 \%)$. The DNA G + C content was $49.1 \mathrm{~mol} \%$. The phylogenetic and phenotypic analyses of strain fav-2-10-05 ${ }^{\top}$ suggested that it belongs to a novel species of the genus Shewanella, for which the name Shewanella corallii sp. nov. is proposed. The type strain is fav $-2-10-05^{\top}\left(=\right.$ LMG $24563^{\top}=$ DSM $\left.21332^{\top}\right)$.
\end{abstract}

The genus Shewanella (family Shewanellaceae, order Alteromonadales, class Gammaproteobacteria) was first described by MacDonell \& Colwell (1985) to accommodate Gram-negative, rod-shaped, facultatively anaerobic gammaproteobacteria. Members of this genus are frequently isolated from aquatic environments and the genus comprises mesophilic and psychrotolerant species (Miyazaki et al., 2006). To date, at least 50 Shewanella species have been recognized (Euzéby, 2007).

Although the genus Shewanella has been studied over the last three decades, little is known of the antibacterial properties of its members. Indeed, only a few taxonomic studies have included tests of antimicrobial activity. Among strains of the genus Shewanella that have been found to possess antimicrobial activity, Shewanella algae $\mathrm{OK}-1^{\mathrm{T}}$ produced tetrodotoxin, a strong neurotoxin (Simidu et al., 1990), and five Shewanella strains isolated from a fish farm tank wall were antagonistic against two larval-pathogenic strains (Hjelm et al., 2004). The Shewanella strains studied by Ivanova et al. (2003) demonstrated weak antimicrobial and antifungal activities and, similarly, Barbieri et al. (1997) reported weak antimicrobial activity for Shewanella pealeana

The GenBank/EMBL/DDBJ accession number for the 16S rRNA gene sequence of strain fav-2-10-05 ${ }^{\top}$ is FJ041083.
(Leonardo et al., 1999). Moreover, it has been hypothesized that tetrodotoxin-producing Shewanella strains may serve a protective role in the marine environment, such as benefiting the eggs of squids of the genus Loligo (Barbieri et al., 2001; Hau \& Gralnick, 2007). In a recent study, coral mucus-associated bacteria were isolated and screened for antibacterial activity (Shnit-Orland \& Kushmaro, 2009). Strain fav-2-10- $05^{\mathrm{T}}$ originated from a scleractinian coral of the genus Favia and demonstrated antibacterial activity against a Gram-positive indicator strain (Shnit-Orland \& Kushmaro, 2009). According to 16S rRNA gene sequence similarity, strain fav-2-10-05 ${ }^{\mathrm{T}}$ was found to belong to the genus Shewanella. This study further describes its taxonomic position.

Coral mucus samples were collected as described by Barneah et al. (2007) from the reef adjacent to the InterUniversity Institute for Marine Science in the Gulf of Eilat, Red Sea, Israel $\left(29.51^{\circ} \mathrm{N} 34.94^{\circ} \mathrm{E}\right)$, in March 2005. After serial dilution and plating, strain fav-2-10-0 $5^{\mathrm{T}}$ was isolated on $10 \%$ marine agar 2216 (MA; HiMedia Laboratories) prepared with artificial seawater after 2-5 weeks of incubation at room temperature. A pure culture was obtained by subcultivation under the same conditions. Screening for antibacterial activity was performed using the drop technique, as detailed by Shnit-Orland \& Kushmaro 
(2009). Further subcultivation was performed on $50 \%$ MA prepared with artificial seawater at $26{ }^{\circ} \mathrm{C}$. The strain was maintained as viable cultures on plates at room temperature and stored as $20 \%(\mathrm{v} / \mathrm{v})$ glycerol suspensions at $-80{ }^{\circ} \mathrm{C}$.

Gram-staining of strain fav-2-10-0 $5^{\mathrm{T}}$ was performed using a Gram-stain kit (Sigma Diagnostics). For scanning electron microscopy, cells were placed on 300-mesh copper grids coated with Formvar and carbon and left to be absorbed for $3 \mathrm{~min}$. Negative staining was achieved with $2 \%(\mathrm{w} / \mathrm{v})$ ammonium molybdate (Riedel-deHaen) for $1 \mathrm{~min}$, with no washing during the staining process and removal of excess liquid with filter paper placed close to the grid. Negatively stained cells were examined using a JEM1230 scanning electron microscope (JEOL) with an acceleration voltage of $120 \mathrm{kV}$. Strain fav-2-10-05 $5^{\mathrm{T}}$ was characterized biochemically using the API 20NE and API ZYM systems (bioMérieux), according to the manufacturer's instructions. Haemolytic activity was tested on tryptic soy blood agar containing $5 \%$ defibrinated sheep blood (Hy-Laboratories) and anaerobic growth was tested on $50 \% \mathrm{MA}$ in an anaerobic cell (Gas Pak EZ; BD).

Cells of strain fav-2-10-05 ${ }^{\mathrm{T}}$ were Gram-negative, nonsporulating rods, approximately $0.8-1 \mu \mathrm{m}$ wide and $2 \mu \mathrm{m}$ long, and motile by means of a single polar flagellum (Fig. 1). Strain fav-2-10-05 $5^{\mathrm{T}}$ formed yellow-brownish colonies within 2 days of incubation at $26{ }^{\circ} \mathrm{C}$ on $50 \%$ MA. Strain fav $-2-10-05^{\mathrm{T}}$ grew under aerobic conditions and grew slowly under anaerobic conditions. The strain was also able to grow in marine broth and Luria-Bertani broth (Hy-Laboratories) and grew weakly in nutrient broth (HiMedia Laboratories). Growth with 0.5, 3, 6, 8, 10 and $15 \% \mathrm{NaCl}$ was tested in nutrient broth. Strain fav-2-10$05^{\mathrm{T}}$ grew with $0.5-6 \% \mathrm{NaCl}$, grew weakly with $8 \% \mathrm{NaCl}$ and did not grow at all with $10 \% \mathrm{NaCl}$. Cells after growth

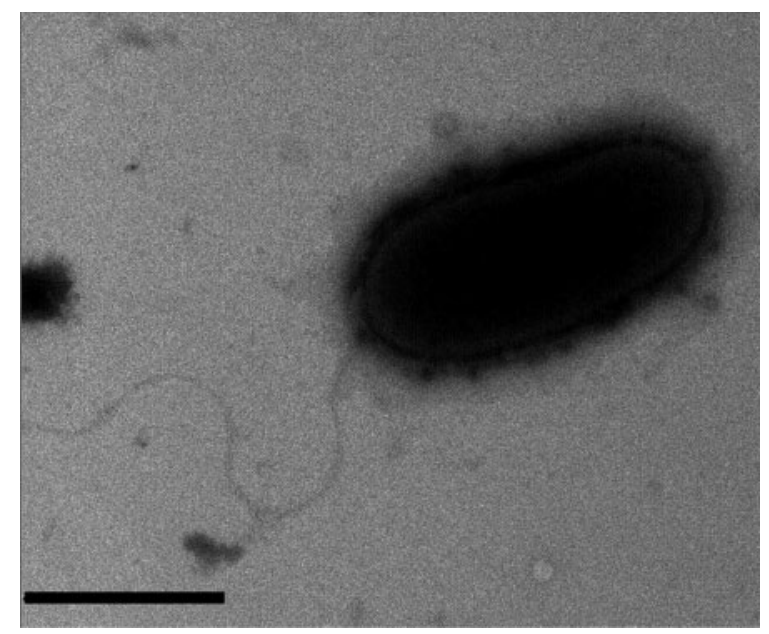

Fig. 1. Scanning electron micrograph of a negatively stained cell of strain fav-2-10-05 ${ }^{\top}$. Bar, $1 \mu \mathrm{m}$. with 0.5 and $8 \% \mathrm{NaCl}$ appeared yellow and did not display the yellow-orange pigment that was observed after growth in liquid medium made with artificial seawater. Strain fav$2-10-05^{\mathrm{T}}$ grew at $10-37{ }^{\circ} \mathrm{C}$ (weakly at $37{ }^{\circ} \mathrm{C}$, optimally at $26{ }^{\circ} \mathrm{C}$ ), but no growth was observed after a week of incubation at 4 or $42{ }^{\circ} \mathrm{C}$.

The profile of enzyme activities was obtained from API ZYM strips after incubation at $26{ }^{\circ} \mathrm{C}$ for 4.5 and $24 \mathrm{~h}$ and at $37^{\circ} \mathrm{C}$ for $4.5 \mathrm{~h}$. Strain fav-2-10-0 $05^{\mathrm{T}}$ showed positive reactions for alkaline phosphatase and $\alpha$-chymotrypsin and weak reactions for esterase (C4), esterase lipase (C8), naphthol-AS-BI-phosphohydrolase and $N$-acetyl- $\beta$-glucosaminidase. All other enzyme tests were negative. Data from API 20 NE strips were obtained after incubation at $26{ }^{\circ} \mathrm{C}$ for 24 and $48 \mathrm{~h}$. Strain fav- $2-10-05^{\mathrm{T}}$ was positive for catalase, oxidase, arginine dihydrolase, fermentation of Dglucose, hydrolysis with $\beta$-glucosidase and protease (gelatinase), reduction of nitrates to nitrites and assimilation of $\mathrm{N}$-acetylglucosamine and maltose. Haemolytic activity was not detected after $48 \mathrm{~h}$ of incubation but was detected after 4 days, after which haemolysis proceeded to form clear zones that surrounded the colonies. Phenotypic characteristics that differentiate strain fav-2-10- $05^{\mathrm{T}}$ from its closest phylogenetic relatives Shewanella marisflavi SW$117^{\mathrm{T}}$, Shewanella haliotis $\mathrm{DW} 01^{\mathrm{T}}$, Shewanella amazonensis $\mathrm{SB} 2 \mathrm{~B}^{\mathrm{T}}$ and Shewanella pneumatophori SCRC- $2738^{\mathrm{T}}$ are shown in Table 1.

Antibiotic resistance was determined by the disc diffusion method using commercial antibiotic discs (Oxoid). The inhibition zone of each antibiotic was measured on MA plates incubated at $26{ }^{\circ} \mathrm{C}$ for $48 \mathrm{~h}$. Strain fav-2-10- $05^{\mathrm{T}}$ was sensitive to ampicillin, chloramphenicol, erythromycin, nalidixic acid, tetracycline and sulphamethoxazole plus trimethoprim and was slightly sensitive to meticillin.

For analysis of cellular fatty acid content, cells of strain fav$2-10-05^{\mathrm{T}}$ cells were prepared on MA plates at $26{ }^{\circ} \mathrm{C}$ and the fatty acid methyl esters were analysed using the MIDI/ Hewlett Packard microbial identification system (Analytical Services, Plant Protection and Inspection Services, Beit-Dagan, Israel). Strain fav-2-10-0 $05^{\mathrm{T}}$ exhibited a cellular fatty acid profile that contained large amounts of straight-chain, branched, unsaturated and hydroxy fatty acids (Table 2). The major cellular fatty acids were $\mathrm{C}_{17: 1} \omega 8 c(21.6 \%)$, iso- $\mathrm{C}_{15: 0}(18.6 \%), \mathrm{C}_{15: 0}(9.1 \%)$ and iso- $\mathrm{C}_{13: 0}(8.9 \%)$. The proportions of the major fatty acids of $S$. marisflavi $\mathrm{SW}-117^{\mathrm{T}}$ and $S$. haliotis $\mathrm{DW} 01^{\mathrm{T}}$, the strains most closely related to strain fav-2-10-0 $5^{\mathrm{T}}$, were largely similar to those of strain fav-2-10-0 ${ }^{\mathrm{T}}$ (Table 2).

Genomic DNA was extracted from strain fav-2-10-05 using an UltraClean Microbial DNA Isolation kit (MoBio Laboratories), according to the manufacturer's instructions. The $16 \mathrm{~S}$ rRNA gene was amplified by PCR with a gradient thermocycler (Mastercycler; Eppendorf) using bacterial 16S rRNA gene primers taken from Felske et al. (1997) with the modification that the forward primer was shortened at the $5^{\prime}$ end [forward primer $8 \mathrm{~F}$, 
Table 1. Phenotypic characteristics that differentiate strain fav$2-10-05^{\top}$ from its closest phylogenetic neighbours

Strains: 1, Shewanella corallii sp. nov. fav-2-10-05 ${ }^{\mathrm{T}} ; 2$, S. marisflavi SW- $117^{\mathrm{T}}$ (data from Yoon et al., 2004); 3, S. haliotis DW01 ${ }^{\mathrm{T}}(\mathrm{Kim}$ et al., 2007); 4, S. amazonensis $\mathrm{SB}_{2 \mathrm{~B}}^{\mathrm{T}}$ (Venkateswaran et al., 1998); 5, S. pneumatophori SCRC- $2738^{\mathrm{T}}$ (Hirota et al., 2005). All strains were Gram-negative, rod-shaped, motile and catalase- and oxidasepositive, hydrolysed gelatin and grew under anaerobic conditions and at $10-32{ }^{\circ} \mathrm{C}$. None of the strains assimilated D-mannose or Dmannitol. + , Positive; - , negative; ND, no data available.

\begin{tabular}{|lccccc|}
\hline Characteristic & $\mathbf{1}$ & $\mathbf{2}$ & $\mathbf{3}$ & $\mathbf{4}$ & $\mathbf{5}$ \\
\hline Growth at/with: & & & & & \\
$4{ }^{\circ} \mathrm{C}$ & - & + & - & + & + \\
$37{ }^{\circ} \mathrm{C}$ & + & + & + & + & - \\
$42{ }^{\circ} \mathrm{C}$ & - & + & + & + & - \\
$6 \% \mathrm{NaCl}$ & + & + & + & - & + \\
$10 \% \mathrm{NaCl}$ & - & - & + & - & $\mathrm{ND}$ \\
Reduction of nitrates & + & + & + & + & - \\
Fermentation of D-glucose & + & $\mathrm{ND}$ & - & - & + \\
Hydrolysis with $\beta$-glucosidase & + & - & - & $\mathrm{ND}$ & - \\
Arginine dihydrolase & + & $\mathrm{ND}$ & - & - & $\mathrm{ND}$ \\
Assimilation of: & & & & & \\
$\quad \mathrm{D}-$ Glucose & - & + & - & $\mathrm{ND}$ & + \\
Maltose & + & + & - & - & - \\
D-Mannose & - & - & - & + & - \\
Capric acid & - & $\mathrm{ND}$ & + & $\mathrm{ND}$ & $\mathrm{ND}$ \\
$\quad$ Malic acid & - & + & + & - & $\mathrm{ND}$ \\
Resistance to ampicillin $(10 \mu \mathrm{gg}$ & - & $\mathrm{ND}$ & + & $\mathrm{ND}$ & $\mathrm{ND}$ \\
per disc) & & & & & \\
DNA G $+\mathrm{C}$ content (mol\%) & 49.1 & 51 & 53.7 & 51.7 & 42.8 \\
& & & & & \\
\hline
\end{tabular}

5'-GGATCCAGACTTTGAT(C/T)(A/C)TGGCTCAG-3'; reverse primer 1512R, 5'-GTGAAGCTTACGG(C/T)TAGCTTGTTACGACTT-3']. The resulting 16S rRNA gene sequences were compared with those in the GenBank database using the BLAST tool (http://www.ncbi.nlm.nih.gov/blast/blast.cgi) and aligned with sequences of representative strains of the genus Shewanella using CLUSTAL $\mathrm{W}$ in the MEGA package (Kumar et al., 2004). A phylogenetic tree was constructed with the neighbour-joining method (Saitou \& Nei, 1987) using the MEGA package. Bootstrap resampling analysis (Felsenstein, 1985) based on 100 replications was performed to estimate the confidence levels of the tree topology.

An almost-complete 16S rRNA gene sequence (1481 bases) was obtained and sequence database searches revealed that strain fav $-2-10-05^{\mathrm{T}}$ was most closely related to the family Shewanellaceae and exhibited the highest 16S rRNA gene sequence similarities with type strains of species of the genus Shewanella, notably S. marisflavi SW $-117^{\mathrm{T}}(96.0 \%)$, isolated from seawater of the Yellow Sea in Korea (Yoon et al., 2004), and S. haliotis DW01 ${ }^{\mathrm{T}}(95.9 \%)$, isolated from the gut microflora of abalone collected from the South Sea, Republic of Korea (Kim et al., 2007). Strain fav-2-10-05 did not exhibit 16S rRNA gene sequence similarities above $97 \%$ with any type strain of the genus Shewanella. The
Table 2. Cellular fatty acid composition of strain fav-2-10-0 $05^{\top}$ and its closest phylogenetic neighbours

Strains: 1, Shewanella corallii sp. nov. fav-2-10-05 ${ }^{\mathrm{T}} ; 2$, S. marisflavi SW-117 ${ }^{\mathrm{T}}$ (data from Yoon et al., 2004); 3, S. haliotis DW01 ${ }^{\mathrm{T}}$ (Kim et al., 2007). tr, Trace amount $(<1 \%)$; , not present; NR, not reported.

\begin{tabular}{|c|c|c|c|}
\hline Fatty acid (\%) & 1 & 2 & 3 \\
\hline \multicolumn{4}{|c|}{ Straight-chain saturated } \\
\hline $\mathrm{C}_{12: 0}$ & 1.5 & 1.6 & 2.2 \\
\hline $\mathrm{C}_{13: 0}$ & 3.7 & 0.5 & NR \\
\hline $\mathrm{C}_{14: 0}$ & 0.7 & 1.5 & 1.9 \\
\hline $\mathrm{C}_{15: 0}$ & 9.1 & 4.1 & 2.8 \\
\hline $\mathrm{C}_{16: 0}$ & 3.5 & 14.5 & 13.4 \\
\hline $\mathrm{C}_{17: 0}$ & 3.6 & 1.9 & 2.5 \\
\hline $\mathrm{C}_{18: 0}$ & 0.1 & NR & 6.5 \\
\hline \multicolumn{4}{|l|}{ Branched saturated } \\
\hline iso- $\mathrm{C}_{11: 0}$ & 0.1 & 2.0 & NR \\
\hline iso- $\mathrm{C}_{13: 0}$ & 8.9 & 5.9 & 4.1 \\
\hline iso- $\mathrm{C}_{14: 0}$ & 0.9 & 0.7 & 1.1 \\
\hline iso- $\mathrm{C}_{15: 0}$ & 18.6 & 22.9 & 17.7 \\
\hline iso- $\mathrm{C}_{16: 0}$ & 0.2 & 0.2 & $\operatorname{tr}$ \\
\hline iso- $\mathrm{C}_{17: 0}$ & 1.1 & 1.6 & 1.6 \\
\hline \multicolumn{4}{|l|}{ Monounsaturated } \\
\hline $\mathrm{C}_{15: 1} \omega 8 c$ & 1.7 & NR & NR \\
\hline $\mathrm{C}_{16: 1} \omega 9 c$ & 0.8 & 0.7 & 1.1 \\
\hline $\mathrm{C}_{17: 1} \omega 6 c$ & 1.9 & 0.6 & $\operatorname{tr}$ \\
\hline $\mathrm{C}_{17: 1} \omega 8 c$ & 21.6 & 5.3 & 10.7 \\
\hline $\mathrm{C}_{18: 1} \omega 7 c$ & 2.7 & 4.1 & 5.4 \\
\hline $\mathrm{C}_{18: 1} \omega 9 c$ & 1.1 & 1.7 & 4.5 \\
\hline \multicolumn{4}{|l|}{ Hydroxy } \\
\hline $\mathrm{C}_{11: 0} 3-\mathrm{OH}$ & 1.0 & NR & NR \\
\hline $\mathrm{C}_{12: 0} 3-\mathrm{OH}$ & 1.0 & 1.3 & 2.0 \\
\hline iso- $\mathrm{C}_{13: 0} 3-\mathrm{OH}$ & 3.5 & 4.5 & - \\
\hline iso- $\mathrm{C}_{15: 0} 3-\mathrm{OH}$ & 1.1 & NR & $\mathrm{NR}$ \\
\hline \multicolumn{4}{|l|}{ Summed features ${ }^{\star}$} \\
\hline 1 & 3.3 & 0.5 & 1.5 \\
\hline 2 & 1.0 & 0.9 & 1.1 \\
\hline 3 & 4.8 & 18.6 & 12.5 \\
\hline
\end{tabular}

${ }^{*}$ Summed features represent two or three fatty acids that cannot be separated by the Microbial Identification System. Summed feature 1 consisted of one or more of $\mathrm{C}_{13: 0} 3-\mathrm{OH}$, iso- $\mathrm{C}_{15: 1}$ I and iso- $\mathrm{C}_{15: 1} \mathrm{H}$. Summed feature 2 consisted of $\mathrm{C}_{14: 0} 3-\mathrm{OH}$ and/or iso- $\mathrm{C}_{16: 1} \mathrm{I}$. Summed feature 3 consisted of $\mathrm{C}_{16: 1} \omega 7 c$ and/or iso- $\mathrm{C}_{15: 0} 2-\mathrm{OH}$.

phylogenetic tree (Fig. 2), based on a comparison of $1169 \mathrm{bp}$ of the 16S rRNA gene sequence, showed that strain fav-2-10-05 $5^{\mathrm{T}}$ clustered with $S$. amazonensis $\mathrm{SB} 2 \mathrm{~B}^{\mathrm{T}}$, Shewanella spongiae $\mathrm{HJ}_{039^{\mathrm{T}}}$ and Shewanella irciniae UST040317-058 ${ }^{\mathrm{T}}$ (bootstrap value of $53 \%$ ) and S. haliotis DW $01^{\mathrm{T}}$ and S. algae ATCC $51192^{\mathrm{T}}$. The topology of the phylogenetic tree and the sequence divergence values supported the findings of the phenotypic and chemotaxonomic analysis that strain fav-2-10-0 $5^{\mathrm{T}}$ represents a novel species of the genus Shewanella.

For the determination of DNA G $+\mathrm{C}$ content, genomic DNA of strain fav-2-10-0 $05^{\mathrm{T}}$ was prepared according to a 


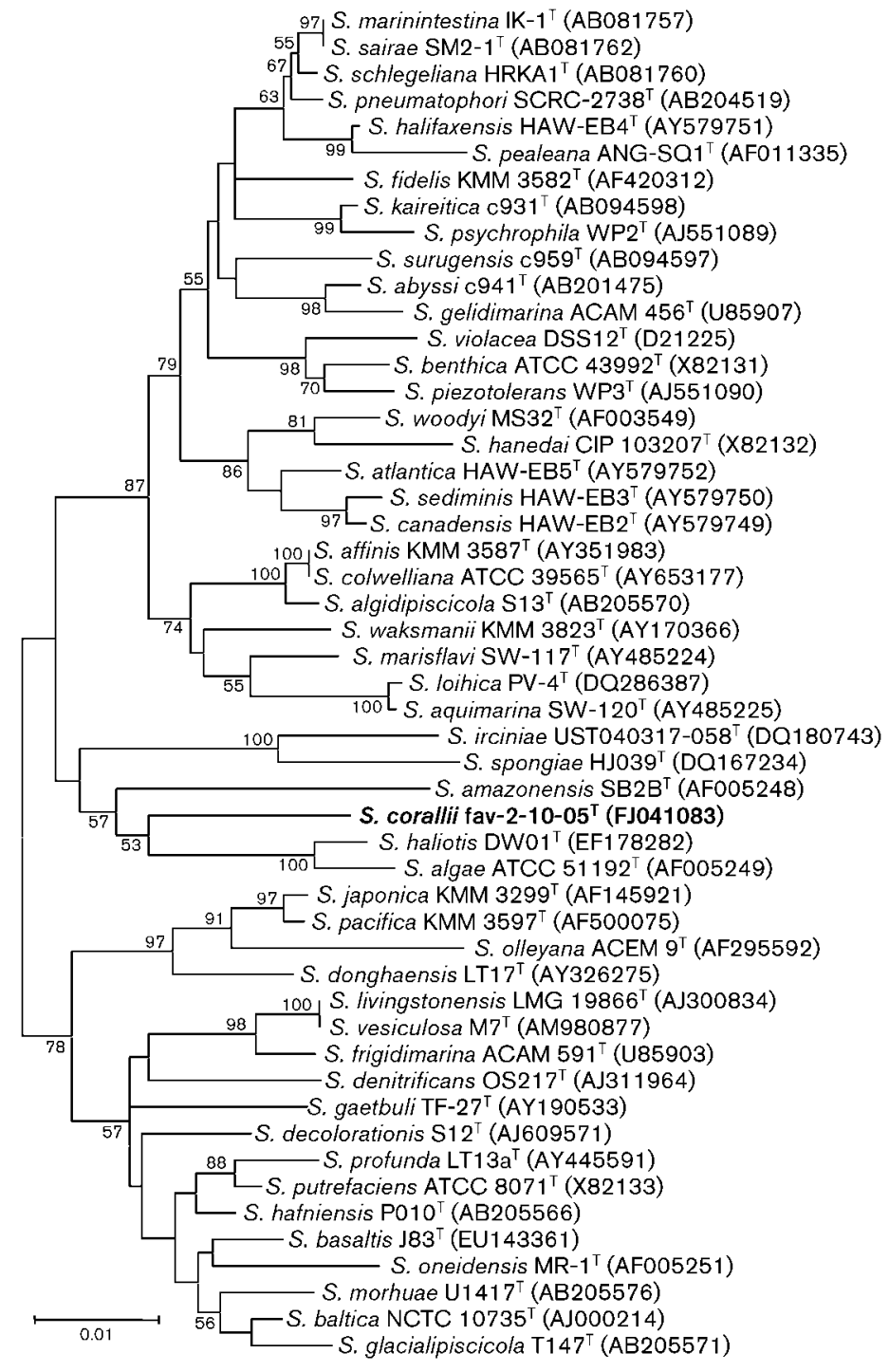

Fig. 2. Neighbour-joining $16 \mathrm{~S}$ rRNA gene sequence phylogeny, based on a comparison of 1169 bases, showing the relationships between strain fav-2-10-05 ${ }^{\top}$ and the type strains of 50 species of the genus Shewanella. Bootstrap values ( $>50 \%$ ) based on 100 replications are shown at branch nodes. Bar, 1 substitution per 100 nucleotide positions. modification of the procedure of Wilson (1987). The G + C content was determined in three independent analyses using the HPLC technique (Mesbah et al., 1989) by the BCCM/LMG Bacteria Collection Identification Service. The DNA $\mathrm{G}+\mathrm{C}$ content of strain fav- $2-10-05^{\mathrm{T}}$ was $49.1 \mathrm{~mol} \%$.

On the basis of phenotypic characterization and phylogenetic analysis, strain fav-2-10-05 $5^{\mathrm{T}}$ should be classified in a novel species of the genus Shewanella, for which the name Shewanella corallii sp. nov. is proposed.

\section{Description of Shewanella corallii sp. nov.}

Shewanella corallii (co.ral'li.i. L. gen. n. corallii of a coral, from which the type strain was isolated).

Cells are Gram-negative, non-spore-forming rods, approximately $0.8-1 \mu \mathrm{m}$ wide and $2 \mu \mathrm{m}$ long, motile by means of a single polar flagellum. Aerobic and catalase- and oxidasepositive, but capable of slow growth under anaerobic conditions. Colonies are yellow-brownish, circular, smooth, opaque and small (approximately $1 \mathrm{~mm}$ in diameter after $24 \mathrm{~h}$ at $26^{\circ} \mathrm{C}$ ). Slightly haemolytic. Grows with $0.5-8.0 \% \mathrm{NaCl}$ and at $10-37{ }^{\circ} \mathrm{C}$. With API ZYM, positive for alkaline phosphatase and $\alpha$-chymotrypsin activities, weakly positive for esterase (C4), esterase lipase (C8), naphthol-AS-BI-phosphohydrolase and $N$-acetyl- $\beta$ glucosaminidase activities, but negative for lipase (C14), cystine arylamidase, leucine arylamidase, valine arylamidase, trypsin, acid phosphatase, $\alpha$ - and $\beta$-galactosidase, $\beta$ glucuronidase, $\alpha$ - and $\beta$-glucosidase, $\alpha$-mannosidase and $\alpha$ fucosidase activities. Positive for arginine dihydrolase, fermentation of D-glucose, hydrolysis with $\beta$-glucosidase and protease (gelatinase), reduction of nitrates to nitrites and assimilation of $\mathrm{N}$-acetylglucosamine and maltose. Negative for indole production, urease, $\beta$-galactosidase and assimilation of D-glucose, L-arabinose, D-mannose, Dmannitol, potassium gluconate, capric acid, adipic acid, malic acid, trisodium citrate and phenylacetic acid. The 
major fatty acids $(>5 \%)$ are $\mathrm{C}_{17: 1} \omega 8 c$, iso- $\mathrm{C}_{15: 0}, \mathrm{C}_{15: 0}$ and iso- $\mathrm{C}_{13: 0}$. Demonstrates antibacterial activity against Bacillus cereus. Sensitive to ( $\mu$ g per disc) ampicillin (10), chloramphenicol, (30), erythromycin (15), meticillin (5), nalidixic acid (30), tetracycline (30) and sulphamethoxazole plus trimethoprim (25). The $\mathrm{G}+\mathrm{C}$ content of the type strain is $49.1 \mathrm{~mol} \%$.

The type strain, fav-2-10-05 $5^{\mathrm{T}}$ (=LMG $24563^{\mathrm{T}}=\mathrm{DSM}$ $21332^{\mathrm{T}}$ ), was isolated from the mucus layer of a specimen of the coral genus Favia from the Gulf of Eilat, Red Sea.

\section{Acknowledgements}

This work was supported by the Israel Science Foundation (grant nos 511/02-1 and 1169/07) and by a Kreitman scholarship to M.S.-O. from the Kreitman School of Advanced Graduate Studies at BenGurion University of the Negev, Israel. The authors wish to thank the IUI, Eilat, Israel for use of their facilities, N. Siboni and E. Ben-Dov for sample collection, technical support and guidance and R. Orland for helpful comments on the manuscript.

\section{References}

Barbieri, E., Barry, K., Child, A. \& Wainwright, N. (1997). Antimicrobial activity in the microbial community of the accessory nidamental gland and egg cases of Loligo pealei (Cephalopoda: Loliginidae). Biol Bull 193, 275-276.

Barbieri, E., Paster, B. J., Hughes, D., Zurek, L., Moser, D. P., Teske, A. \& Sogin, M. L. (2001). Phylogenetic characterization of epibiotic bacteria in the accessory nidamental gland and egg capsules of the squid Loligo pealei (Cephalopoda: Loliginidae). Environ Microbiol 3, 151167.

Barneah, O., Ben-Dov, E., Kramarsky-Winter, E. \& Kushmaro, A. (2007). Characterization of black band disease in Red Sea stony corals. Environ Microbiol 9, 1995-2006.

Euzéby, J. P. (2007). List of Prokaryotic Names with Standing in Nomenclature. Accessed 6 May 2009. http://www.bacterio.cict.fr

Felsenstein, J. (1985). Confidence limits on phylogenies: an approach using the bootstrap. Evolution 39, 783-791.

Felske, A., Rheims, H., Wolterink, A., Stackebrandt, E. \& Akkermans, A. D. L. (1997). Ribosome analysis reveals prominent activity of an uncultured member of the class Actinobacteria in grassland soils. Microbiology 143, 2983-2989.

Hau, H. H. \& Gralnick, J. A. (2007). Ecology and biotechnology of the genus Shewanella. Annu Rev Microbiol 61, 237-258.

Hirota, K., Nodasaka, Y., Orikasa, Y., Okuyama, H. \& Yumoto, I. (2005). Shewanella pneumatophori sp. nov., an eicosapentaenoic acidproducing marine bacterium isolated from the intestines of Pacific mackerel (Pneumatophorus japonicus). Int J Syst Evol Microbiol 55, 2355-2359.
Hjelm, M., Riaza, A., Formoso, F., Melchiorsen, J. \& Gram, L. (2004). Seasonal incidence of autochthonous antagonistic Roseobacter spp. and Vibrionaceae strains in a turbot larva (Scophthalmus maximus) rearing system. Appl Environ Microbiol 70, 7288-7294.

Ivanova, E. P., Sawabe, T., Zhukova, N. V., Gorshkova, N. M., Nedashkovskaya, O. I., Hayashi, K., Frolova, G. M., Sergeev, A. F., Pavel, K. G. \& other authors (2003). Occurrence and diversity of mesophilic Shewanella strains isolated from the North-West Pacific Ocean. Syst Appl Microbiol 26, 293-301.

Kim, D., Baik, K. S., Kim, M. S., Jung, B. M., Shin, T. S., Chung, G. H., Rhee, M. S. \& Seong, C. N. (2007). Shewanella haliotis sp. nov., isolated from the gut microflora of abalone, Haliotis discus hannai. Int J Syst Evol Microbiol 57, 2926-2931.

Kumar, S., Tamura, K. \& Nei, M. (2004). MEGA3: integrated software for molecular evolutionary genetics analysis and sequence alignment. Brief Bioinform 5, 150-163.

Leonardo, M. R., Moser, D. P., Barbieri, E., Brantner, C. A., MacGregor, B. J., Paster, B. J., Stackebrandt, E. \& Nealson, K. H. (1999). Shewanella pealeana sp. nov., a member of the microbial community associated with the accessory nidamental gland of the squid Loligo pealei. Int J Syst Bacteriol 49, 1341-1351.

MacDonell, M. T. \& Colwell, R. R. (1985). Phylogeny of the Vibrionaceae, and recommendation for two new genera, Listonella and Shewanella. Syst Appl Microbiol 6, 171-182.

Mesbah, M., Premachandran, U. \& Whitman, W. B. (1989). Precise measurement of the $\mathrm{G}+\mathrm{C}$ content of deoxyribonucleic acid by highperformance liquid chromatography. Int J Syst Bacteriol 39, 159-167.

Miyazaki, M., Nogi, Y., Usami, R. \& Horikoshi, K. (2006). Shewanella surugensis sp. nov., Shewanella kaireitica sp. nov. and Shewanella abyssi sp. nov., isolated from deep-sea sediments of Suruga Bay, Japan. Int J Syst Evol Microbiol 56, 1607-1613.

Saitou, N. \& Nei, M. (1987). The neighbor-joining method: a new method for constructing phylogenetic trees. Mol Biol Evol 4, 406-425.

Shnit-Orland, M. \& Kushmaro, A. (2009). Coral mucus-associated bacteria: a possible first line of defense. FEMS Microbiol Ecol 67, 371380.

Simidu, U., Tsukamoto, K. K., Yasumoto, T. \& Yotsu, M. (1990). Taxonomy of four marine bacterial strains that produce tetrodotoxin. Int J Syst Bacteriol 40, 331-336.

Venkateswaran, K., Dollhopf, M. E., Aller, R., Stackebrandt, E. \& Nealson, K. H. (1998). Shewanella amazonensis sp. nov., a novel metal-reducing facultative anaerobe from Amazonian shelf muds. Int J Syst Bacteriol 48, 965-972.

Wilson, K. (1987). Preparation of genomic DNA from bacteria. In Current Protocols in Molecular Biology, pp. 2.4.1-2.4.5. Edited by F. M. Ausubel, R. Brent, R. E. Kingston, D. D. Moore, J. G. Seidman, J. A. Smith \& K. Struhl. New York: Greene Publishing and Wiley-Interscience.

Yoon, J. H., Yeo, S. H., Kim, I. G. \& Oh, T. K. (2004). Shewanella marisflavi sp. nov. and Shewanella aquimarina sp. nov., slightly halophilic organisms isolated from sea water of the Yellow Sea in Korea. Int J Syst Evol Microbiol 54, 2347-2352. 